\title{
Study on the migration and transformation characteristics of arsenic and antimony in the rhizosphere of plants grown in zinc smelting waste residue
}

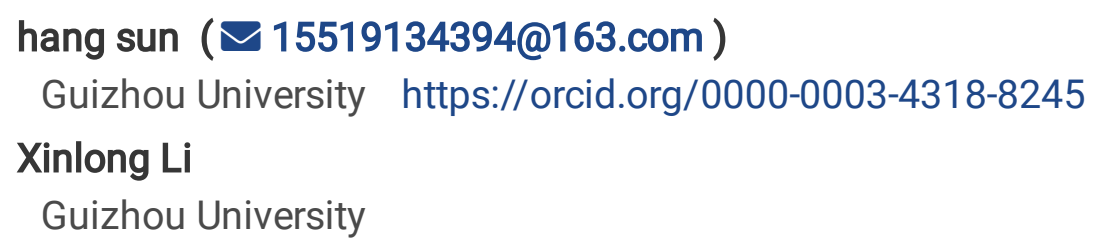

Research

Keywords: Zinc smelting slag, Phytoremediation, Arsenic, Antimony, Migration and transformation

Posted Date: February 13th, 2020

DOI: https://doi.org/10.21203/rs.2.23494/v1

License: @ (i) This work is licensed under a Creative Commons Attribution 4.0 International License. Read Full License 


\section{Abstract}

Background: In this paper, the physical and chemical characteristics of the rhizospheres of Broussonetia papyrifera, Cryptomeria fortunei, Arundo donax, Robinia pseudoacacia, Photinia serrulata and Lolium perenne grown in indigenous $\mathrm{Zn}$-smelting waste residue were studied, and the effects of the rhizosphere on the migration and transformation of arsenic and antimony in waste residue were investigated.

Results: The results showed that compared with the control waste residue, the $\mathrm{pH}$ and Eh of the waste residues from the rhizospheres of the six plants decreased significantly $(P<0.05)$, and the dissolved organic carbon (DOC) content increased significantly $(P<0.05)$. The peak strength of hydroxyl groups, aliphatic groups, aromatic groups, calcite and quartz in the rhizosphere waste residue decreased to different degrees compared with that of the control waste residue, and the peak strength of carbohydrates/organosilicates increased. Overall, the contents of arsenic and antimony in the rhizosphere waste residues of the 6 plants were lower than those of the control waste residue, and the contents of arsenic(III) and antimony(III) were significantly higher than those of arsenic $(\mathrm{V})$ and antimony $(\mathrm{V})$, respectively $(P<0.05)$. The proportions of residual arsenic and antimony in the rhizosphere waste residues were the highest, and the proportion was significantly higher than that of control waste residue, and the proportions of exchangeable state, the aluminum-bound state and the calcium-bound state were lower than that in the control waste residue. The contents of arsenic and antimony in the tissues of the six plants followed the order of roots > leaves > stems, and the enrichment coefficients of arsenic and antimony in different plants were low.

Conclusion: After 7 years of phytoremediation, the content and bioavailability of arsenic and antimony in the waste residue were significantly reduced, and the enrichment of arsenic and antimony in plant tissue was also low. It is speculated that the migration of arsenic and antimony in waste residue may increase in the early stage of phytoremediation and gradually stabilize in the later stage.

\section{Background}

Arsenic and antimony are sulfophilic elements widely found in nature, having similar chemical properties, toxicological properties, and geochemical behaviors, as well as metallic properties and nonmetallic properties [1]. Various arsenic and antimony pollutants have been shown to be toxic and carcinogenic to humans and organisms and to cause diseases of the liver, skin, and respiratory and cardiovascular systems [2, 3]; furthermore, these compounds have been listed as priority pollutants by the EPA and EU [4]. The toxicity of arsenic and antimony in the environment depends on their morphology, and the toxicity of arsenic and antimony in general follows the order organic arsenic and antimony < pentavalent arsenic and antimony < trivalent arsenic and antimony [5, 6]. Arsenic and antimony often co-occur in sulfur-rich ores [7], so cocontamination of arsenic and antimony is common in mining areas [8]. In recent years, the copollution of arsenic and antimony in the environment has received extensive attention from many scholars and has become a research hotspot in the field of environmental science $[9,10 ; 11]$.

Mineral mining, smelting and other human activities are important ways to accelerate arsenic and antimony transport into the environment. Northwestern Guizhou is a typical indigenous zinc smelting area in China. Indigenous zinc smelting slag is a highly heterogeneous and complicated mixture (including smelting slag, ceramic zinc smelting pot fragments, coal cinder, products of the incomplete combustion of coal, etc.) 
characterized by a poor physical structure, a poor nutrient content, alkaline $\mathrm{pH}$, a variety of high-content heavy metals and low biological activity [12]. Under natural conditions, almost nothing grows in waste residue. Phytoremediation is generally considered an effective and low-consumption method to clean soil [13]. The use of plants for the restoration of waste residue yards and abandoned land is of great significance to effectively control the diffusion of heavy metals to the surrounding environment and to realize the restoration of polluted environments and damaged ecosystems.

As the rhizosphere microenvironment is the first to respond to plant pollution stress, it has become an important microdomain for studying the interactions among plants, soil and microorganisms due to its special physical, chemical and biological characteristics [14]. The rhizosphere microenvironment of plants plays an important role in the biogeochemical processes of heavy metals in waste residues [15], the physicochemical properties of tailings and microbial activity [16]. However, studies on the physical and chemical properties of rhizosphere residues under different plants and the migration and transformation characteristics of arsenic and antimony are rarely reported. Therefore, in this paper, six different types of plants that had been growing healthily for 7 years in an indigenous zinc smelting waste residue yard in northwestern Guizhou, China, were studied to explore the effects of the changes in the physical and chemical characteristics of the waste residue induced by plant activity on the migration and transformation characteristics of arsenic and antimony in the waste residue; the results provide a scientific basis for the phytoremediation of sites polluted with arsenic and antimony compounds.

\section{Materials And Methods}

\section{Study area description}

The study area is located in Qunfa village, Houchang town, Weining County, Guizhou Province, China (26 $41^{\circ} 14$ “ $\mathrm{N}, 104^{\circ} 43^{\prime} 45^{\prime \prime} \mathrm{E}$ ). The average annual temperature is $10^{\circ} \mathrm{C}$, the average annual precipitation is $890 \mathrm{~mm}$, the average annual sunshine hours are $1800 \mathrm{~h}$, the frost-free period is $180 \mathrm{~d}$, and the average altitude is $2200 \mathrm{~m}$, belonging to the subtropical monsoon climate. In 2012, the research group carried out an ecological restoration project at an indigenous zinc smelting waste residue yard in the research area. The engineering measures taken were as follows: first, the waste residue yard was leveled; then, the natural mineral heavy metal passivator (containing $23 \%$ calcium and $17 \%$ silicon) and organic improvers (manure, plant litter and moss) was broadcasted to improve the physical and chemical properties of the waste dump. Finally, Lolium perenne, Broussonetia papyrifera, Cryptomeria fortunei, Arundo donax and Robinia pseudoacacia were selected as the pioneer plants to carry out ecological restoration. As the plant characteristics of the waste residue improved, Photinia serrulata and other native plants also heavily populated the waste residue.

\section{Indigenous zinc smelting process}

The main operating sequence of indigenous zinc smelting is ore dressing $\rightarrow$ crushing $\rightarrow$ furnace loading $\rightarrow$ heating and smelting $\rightarrow$ zinc extraction $\rightarrow$ dissolution and casting. First, after mechanical crushing, the zinc ore and coal are sieved at a certain mixing proportion, followed by blending. The material is loaded into a ceramic jar, and the gap between the jar and jar is filled with coal. Finally, the coal is burned, and the zinc ore in in the smelting pot is melted. The difference in the boiling points of lead and zinc enables zinc refining. During the 
smelting process, the temperature in the reaction section of the smelting tank can be as high as $1200^{\circ} \mathrm{C}$ or above, while the temperature at the top of the smelting tank is only approximately $800^{\circ} \mathrm{C}$. In this way, the volatile gases from zinc smelting can be condensed, and crude zinc can be extracted.

The zinc ores used in smelting mainly include zinc sulfide ores $(\mathrm{ZnS})$ and zinc carbonate ores $\left(\mathrm{ZnCO}_{3}\right)$. The basic principle of zinc smelting is shown in the equation below [12]:

\section{$2 \mathrm{ZnS}+3 \mathrm{C}+5 \mathrm{O}_{2}=2 \mathrm{Zn}+3 \mathrm{CO}_{2}+5 \mathrm{SO}_{2}$ or $2 \mathrm{ZnCO}{ }_{3}+\mathrm{C}=2 \mathrm{Zn}+3 \mathrm{CO}_{2}$}

\section{Sample collection}

The Zn-smelting waste residue was divided into two different types: (1) control waste residue area, where no vegetation was present, and (2) vegetated area, where six plant species Lolium perenne, Broussonetia papyrifera, Cryptomeria fortunei, Arundo donax and Robinia pseudoacacia were grown for seven years. The spacing of each plant was $1 \mathrm{~m}$ and $3 \mathrm{~m}$, respectively. The vegetated area was divided into five quadrats, in December 2018, samples were collected from five quadrats in the study area. Samples of rhizosphere and nonrhizosphere waste residues of Lolium perenne, Broussonetia papyrifera, Cryptomeria fortunei, Arundo donax and Robinia pseudoacacia of similar age and growth were collected within each quadrat. Control waste residue samples and plant tissue samples were also collected. No-rhizosphere slag was randomly collected at a fixed depth of $0-20 \mathrm{~cm}$ at a distance greater than $50 \mathrm{~cm}$ from the rhizosphere of each plant species in order to avoid the impact of the root. The rhizosphere fraction of the waste slag was obtained from the root surface $(0-5 \mathrm{~mm}$, strong adherence to the root) after gentle shaking of the root by hand. Control samples of waste residue were randomly collected from the surface $(0-20 \mathrm{~cm})$ of the control waste residue area. Plant rhizosphere slag samples were collected according to Riley $[17,18]$ by the shake-off method. After the collected waste residue samples were brought back to the laboratory, the excess material was removed, and samples of the same plant species from different sites were mixed evenly and air-dried to constant weight at room temperature. After collection and transportation to the laboratory, Broussonetia papyrifera, Cryptomeria fortunei, Arundo donax, Robinia pseudoacacia and Photinia serrulata samples were divided into roots, stems and leaves, and Lolium perenne samples were divided into roots and leaves.

\section{Sample analysis}

The $\mathrm{pH}$ and Eh were determined by the potentiometric method (waste residue:water = 1:2.5). Referring to the method of Bolan et al. [19], DOC was extracted and determined by a TOC-2000 instrument (Shanghai Yuanxi Company). Free ferric oxide and aluminum were extracted with sodium bisulfite and determined by spectrophotometry [20].

Fourier-transform infrared spectroscopy analysis (FTIR): Dried powder samples were mixed with $\mathrm{KBr}$ at a ratio of 1:150 and then pressed into slices. An FTIR-850 (Tianjin Gangdong Company) was used to collect infrared spectra in the range of $400-4000 \mathrm{~cm}^{-1}$ with a resolution of $4 \mathrm{~cm}^{-1}$.

Analysis of arsenic and antimony in waste residue: The determination of arsenic and antimony was performed according to the Chinese standard (HJ680-2013). The valence states of arsenic and antimony were separated 
by extraction with $0.1 \mathrm{~mol} \cdot \mathrm{L}^{-1}$ citric acid ( $\left.\mathrm{pH} 2.08\right)$, and the concentrations of arsenic(III) and antimony(III) in the extract were determined by AFS (AFS-8530, Beijing Haiguang). Then, the contents of arsenic(V) and antimony $(V)$ extracted by citric acid were determined by subtracting the contents of antimony(III) and arsenic(III) from the contents of arsenic and antimony, respectively [21,22,23]. The classification method for the continuous extraction of phosphorus was adapted to divide the arsenic and antimony fractions into the exchangeable state, aluminum-bound state, iron-bound state, calcium-bound state and residual state [24,25]. The arsenic and antimony contents in the extract were determined by ICP-AES (Shimadzu 9820, Japan).

Determination of arsenic and antimony in plant tissues: Plant samples $(0.5 \mathrm{~g})$ were accurately weighed, and 3 $\mathrm{mL}$ of high-purity nitric acid was added for digestion. The contents of arsenic and antimony in the digestion solution were determined by hydride generation and atomic fluorescence spectrometry (AFS-8530, Beijing Haiguang).

Blank and parallel samples were prepared for each step of the above experiment, and the measurement results were averaged.

\section{Data processing}

All statistical analyses were carried out using SPSS for Windows (Version 25.0). The results are expressed as the means \pm standard deviation. All data were analyzed using one-way ANOVA to assess the differences among treatments. The differences between the means were determined using the Duncan multiple range test and were considered as significant at $p<0.05$. Principal component analysis (SD) was performed by Canoco 5 . And the graphics were drawn using Origin 2018.

\section{Results}

\section{Influence of phytoremediation on physicochemical properties of waste residue}

The physical and chemical properties of the waste residue are shown in Table 1. After phytoremediation, there was no significant difference in $\mathrm{pH}$ value between the rhizosphere waste residue of Cryptomeria fortunei and the control waste residue ( $P>0.05)$. The $\mathrm{pH}$ value of the rhizosphere waste residues of other plants was significantly lower $(P<0.05)$ than that of the control waste residue, and the $\mathrm{pH}$ values of the rhizosphere waste residues of the six plants were $0.02-0.42$ lower than that of the control waste residue. The waste residue Eh ranged from 147.55-211.00 mV; the Eh of Lolium perenne rhizosphere waste residue was significantly higher $(P<0.05)$ than that of the nonrhizosphere waste residue and control waste residue. The Eh of other plant rhizosphere waste residues $(P<0.05)$ was significantly lower than that of the control waste residue and lower than that of nonrhizosphere waste residue; among the results, the Eh of Cryptomeria fortunei rhizosphere waste residue was the lowest, and that of Lolium perenne rhizosphere waste residue was the highest. The DOC content in the slag ranged from 6.14 to $20.77 \mathrm{mg} \cdot \mathrm{L}^{-1}$. Among the $6 \mathrm{kinds}$ of plant rhizosphere slag, the DOC content was significantly $(P<0.05)$ higher than that of the control slag; the value in the plant rhizosphere slag was increased by $12.15-14.63 \mathrm{mg} \cdot \mathrm{L}^{-1}$. The DOC content of the rhizosphere waste residue was significantly $(P<0.05)$ higher than that of the nonrhizosphere waste residue. The DOC contents in the 6 kinds of plant 
rhizosphere slag, from high to low, followed the order Broussonetia papyrifera > Lolium perenne > Robinia pseudoacacia $>$ Arundo donax $>$ Photinia serrulata $>$ Photinia serrulata.

The content of free iron oxide in the waste residue varied from 773.90 to $1917.17 \mathrm{mg} \cdot \mathrm{kg}^{-1}$. The content of free iron oxide in waste residues from the rhizospheres of Cryptomeria fortunei, Photinia serrulataand Lolium perennewas significantly higher than that of the control waste residue $(P<0.05)$, and the content of free iron oxide in waste residue from the rhizosphere of Broussonetia papyrifera was significantly lower than that of the control waste residue $(P<0.05)$. The content of free iron oxide in waste residues from the rhizospheres of Arundo donax and Robinia pseudoacacia was not significantly different from that of the control waste residue $(P>0.05)$. The content of free iron oxide in the rhizosphere waste residues of Broussonetia papyrifera and Robinia pseudoacacia was significantly lower than that of nonrhizosphere waste residue $(P<0.05)$, and the content of free iron oxide in the rhizosphere waste residues of Photinia serrulata and Lolium perenne was significantly higher than that of nonrhizosphere waste residue $(P<0.05)$. The content of free iron oxide in Lolium perenne rhizosphere waste residue was the highest. The content of free aluminum oxide varied from 5053.72 to $7550.33 \mathrm{mg} \cdot \mathrm{kg}^{-1}$. The content of free aluminum oxide in the rhizosphere waste residue of Broussonetia papyrifera was significantly higher than that of the control waste residue $(P<0.05)$, the content of free aluminum oxide in the rhizosphere waste residues of Arundo donax and Robinia pseudoacacia was significantly lower than that of the control waste residue $(P<0.05)$, and the content of free aluminum oxide in the rhizosphere waste residues of Cryptomeria fortunei, Photinia serrulata and Lolium perenne was not significantly different from that of the control waste residue ( $P>0.05)$. The content of free alumina in the rhizosphere waste residues of Broussonetia papyrifera and Robinia pseudoacacia was significantly higher than that of nonrhizosphere waste residue $(P<0.05)$, and the content of free alumina in the rhizosphere waste residues of Arundo donax and Robinia pseudoacacia was significantly lower than that of nonrhizosphere waste residue $(P<0.05)$. The content of free alumina in the rhizosphere waste residue of Arundo donax was the lowest, while the content of free alumina in the rhizosphere waste residue of Broussonetia papyrifera was the highest.

\section{Table 1 Influence of phytoremediation on physicochemical properties of waste residue}




\begin{tabular}{|llllll|}
\hline Treatment & pH & Eh & DOC & Fed & Ald \\
\cline { 3 - 6 } & & $\mathrm{mV}$ & $\mathbf{m g} \cdot \mathrm{L}^{-1}$ & $\mathbf{m g} \cdot \mathrm{kg}^{-1}$ & $\mathrm{mg}^{-1} \mathbf{k g}^{-1}$ \\
\hline CWR & $7.64 \pm 0.01 \mathrm{~g}$ & $205 \pm 5.37 \mathrm{gh}$ & $6.14 \pm 0.20 \mathrm{a}$ & $1232.79 \pm 134.27 \mathrm{bc}$ & $7033.73 \pm 114.44 \mathrm{~d}$ \\
\hline BR & $7.32 \pm 0.03 \mathrm{c}$ & $179.8 \pm 4.95 \mathrm{~cd}$ & $20.77 \pm 0 \mathrm{~h}$ & $773.9 \pm 22.38 \mathrm{a}$ & $7550.33 \pm 110.02 \mathrm{e}$ \\
\hline BNR & $7.47 \pm 0.06 \mathrm{e}$ & $195.65 \pm 3.61 \mathrm{efg}$ & $14.30 \pm 1.19 \mathrm{~cd}$ & $1478.06 \pm 33.57 \mathrm{gh}$ & $7003.77 \pm 257.49 \mathrm{~d}$ \\
\hline CR & $7.62 \pm 0.07 \mathrm{~g}$ & $147.55 \pm 6.29 \mathrm{a}$ & $15.65 \pm 0.21 \mathrm{e}$ & $1343.56 \pm 22.38 \mathrm{def}$ & $6634.09 \pm 97.02 \mathrm{~cd}$ \\
\hline CNR & $7.41 \pm 0.01 \mathrm{~d}$ & $156.15 \pm 2.76 \mathrm{ab}$ & $14.46 \pm 0.02 \mathrm{~d}$ & $1422.68 \pm 89.51 \mathrm{fg}$ & $6582.27 \pm 657.36 \mathrm{~cd}$ \\
\hline AR & $7.41 \pm 0.01 \mathrm{~d}$ & $187.1 \pm 1.41 \mathrm{de}$ & $16.86 \pm 1.32 \mathrm{f}$ & $1292.13 \pm 58.43 \mathrm{cde}$ & $5053.72 \pm 2188.91 \mathrm{a}$ \\
\hline ANR & $7.27 \pm 0.08 \mathrm{bc}$ & $200.1 \pm 8.34 \mathrm{fgh}$ & $14.55 \pm 0.78 \mathrm{de}$ & $1394.99 \pm 27.97 \mathrm{efg}$ & $6625.06 \pm 255.21 \mathrm{~cd}$ \\
\hline RR & $7.39 \pm 0.04 \mathrm{~d}$ & $161.45 \pm 10.82 \mathrm{~b}$ & $18.62 \pm 0.69 \mathrm{~g}$ & $1181.36 \pm 117.49 \mathrm{~b}$ & $5822.16 \pm 884.22 \mathrm{~b}$ \\
\hline RNR & $7.53 \pm 0.05 \mathrm{f}$ & $172.7 \pm 14.71 \mathrm{c}$ & $13.36 \pm 0.02 \mathrm{~cd}$ & $1300.04 \pm 16.78 \mathrm{cde}$ & $6664.39 \pm 92.34 \mathrm{~cd}$ \\
\hline PR & $7.22 \pm 0.04 \mathrm{a}$ & $211 \pm 21.21 \mathrm{~h}$ & $13.19 \pm 0.02 \mathrm{bc}$ & $1410.81 \pm 106.3 \mathrm{fg}$ & $6374.98 \pm 326.92 \mathrm{~cd}$ \\
\hline PNR & $7.3 \pm 0.03 \mathrm{bc}$ & $185.1 \pm 8.49 \mathrm{de}$ & $12.15 \pm 1.03 \mathrm{~b}$ & $1284.22 \pm 16.78 \mathrm{~cd}$ & $6716.04 \pm 18.2 \mathrm{~cd}$ \\
\hline LR & $7.26 \pm 0.06 \mathrm{ab}$ & $185.6 \pm 6.36 \mathrm{de}$ & $18.94 \pm 0.43 \mathrm{~g}$ & $1917.17 \pm 173.43 \mathrm{i}$ & $6886.73 \pm 371.39 \mathrm{~d}$ \\
\hline LNR & $7.33 \pm 0.02 \mathrm{c}$ & $192.5 \pm 7.78 \mathrm{ef}$ & $20.42 \pm 0.32 \mathrm{~h}$ & $1525.53 \pm 11.19 \mathrm{~h}$ & $6945.02 \pm 217.16 \mathrm{~d}$ \\
\hline
\end{tabular}

$\mathrm{CWR}=$ Control waste residue; $\mathrm{BR}=$ Broussonetia papyrifera rhizosphere waste residue; $\mathrm{BNR}=$ Broussonetia papyrifera nonrhizosphere waste residue; $\mathrm{CR}=$ Cryptomeria fortunei rhizosphere waste residue; $\mathrm{CNR}$

= Cryptomeria fortunei nonrhizosphere waste residue; $\mathrm{AR}$ = Arundo donax rhizosphere waste residue; ANR = Arundo dona $x$ nonrhizosphere waste residue; $\mathrm{RR}=$ Robinia pseudoacacia rhizosphere waste residue; $\mathrm{RNR}$ = Robinia pseudoacacia nonrhizosphere waste residue; $\mathrm{PR}=$ Photinia serrulata rhizosphere waste residue; PNR = Photinia serrulata nonrhizosphere waste residue; $\mathrm{LR}=$ Lolium perenne rhizosphere waste residue; $\mathrm{LNR}$ $=$ Lolium perenne nonrhizosphere waste residue; the same applies below. $F e d=$ free iron oxide; $A$ ld $=$ free aluminum oxide. Different lowercase letters indicate significant differences at $P<0.05$.

\section{Influence of phytoremediation on the chemical structure of waste residue}

The waste residue was characterized by Fourier-transform infrared spectroscopy, and the characterization results are shown in Figure 1. According to the classification of the infrared absorption peaks [26,27,28], 3411 $\mathrm{cm}^{-1}$ corresponds to the stretching vibration of hydroxyl groups. The telescopic vibrations of $\mathrm{CH} 3$ and $\mathrm{CH} 2$ in aliphatic groups occur near 2922 and $2852 \mathrm{~cm}^{-1}$, respectively. The peak at $1624 \mathrm{~cm}^{-1}$ comes from $\mathrm{C}=0$ in aromatic amides. The peaks at 1439 and $876 \mathrm{~cm}^{-1}$ are characteristic peaks of calcite-based calcium carbonate. The peak at $1086 \mathrm{~cm}^{-1}$ may be due to $\mathrm{C}-0$ stretching vibrations in carbohydrates or Si-O stretching vibrations in organosilicates. The twin peaks at 798 and $780 \mathrm{~cm}^{-1}$ are typical quartz peaks, corresponding to the stretching vibrations of $\mathrm{Si}-\mathrm{O}$ bonds in quartz crystals perpendicular to and parallel to the optical axis. The peak at $698 \mathrm{~cm}^{-1}$ corresponds to carboxyl group bending deformation vibrations. The peaks at 521 and 465 $\mathrm{cm}^{-1}$ may be due to Si-O-Al and Si-O-Mg bending vibrations in montmorillonite. The results of infrared spectral 
analysis showed that the peak strength of hydroxyl groups, aliphatic groups, aromatic groups, calcite and quartz in the rhizosphere waste residue of the 6 kinds of plants after restoration decreased to different degrees compared with the control waste residue and the peak strength of carbohydrates/organosilicates.

\section{Effects of phytoremediation on the contents of arsenic and antimony in waste residue}

The contents of arsenic and antimony in the waste residues are shown in Figure 2. Compared with the control waste residue, the content of arsenic in the waste residues under different phytoremediation effects varied; the content of arsenic in the rhizosphere waste residues of Broussonetia papyrifera, Cryptomeria fortunei, Arundo donax and Robinia pseudoacacia was significantly lower than that of the control waste residue $(P<0.05)$, and the content of arsenic in the rhizosphere waste residues of Photinia serrulata and Lolium perenne was significantly higher than that of the control waste residue $(P<0.05)$. The contents of arsenic in the rhizosphere waste residue of different plants were also different. The contents of arsenic in the rhizosphere waste residues of Cryptomeria fortunei and Lolium perenne were significantly higher than that of nonrhizosphere waste residue $(P<0.05)$, and the contents of arsenic in the rhizosphere waste residues of Broussonetia papyrifera, Robinia pseudoacacia and Photinia serrulata were significantly lower than that of nonrhizosphere waste residue $(P<0.05)$. The content of arsenic in the rhizosphere waste residues of Photinia serrulata and Lolium perenne was significantly higher than that in the corresponding residues of the other four plants $(P<0.05)$, and there was no significant content of arsenic in the rhizosphere waste residues of the other four plants $(P>0.05)$.

The effect of the six phytoremediation treatments on the content of antimony in the waste residue followed a similar rule; that is, the content of antimony in the waste residues of the six rhizospheres was significantly lower than that of the control waste residue $(P<0.05)$, with a decrease of $78.46-712.61 \mathrm{mg} \cdot \mathrm{kg}^{-1}$. However, the content of antimony in the rhizosphere and nonrhizosphere waste residue of different plants exhibited different trends: the content of antimony in the rhizosphere waste residues of Broussonetia papyrifera and Robinia pseudoacacia was significantly lower $(P<0.05)$ than that in nonrhizosphere waste residue, and the content of antimony in the rhizosphere waste residues of other plants was not significantly different $(P>0.05)$. The content of antimony in the rhizosphere residues of the 6 plants was, from high to low, Lolium perenne > Photinia serrulata > Broussonetia papyrifera > Cryptomeria fortunei $>$ Arundo donax $>$ Robinia pseudoacacia.

\section{Effects of phytoremediation on the valence characteristics of arsenic and antimony in waste residue}

As can be seen from Figure 3, the content of inorganic arsenic in the control waste residue was $927.77 \mathrm{mg} \cdot \mathrm{kg}^{-}$ 1 , and the content of inorganic arsenic in the plant rhizosphere and nonrhizosphere waste residue was 501.36$689.81 \mathrm{mg} \cdot \mathrm{kg}^{-1}$. The content of arsenic(III) in the waste residue was significantly higher $(P<0.05)$ than that of arsenic $(\mathrm{V})$, and the content of arsenic(III) and arsenic $(\mathrm{V})$ in the rhizosphere waste residues of the six plants was significantly lower $(P<0.05)$ than that in the control waste residue. The content of arsenic(III) and arsenic $(\mathrm{V})$ in the rhizosphere waste residue was lower than that in the nonrhizosphere waste residue. The contents of arsenic(III) and arsenic(V) in the rhizosphere waste residues of the six plants were as follows, from high to low: Lolium perenne > Robinia pseudoacacia > Arundo donax> Cryptomeria fortunei > Broussonetia papyrifera.> 
Photinia serrulata. The inorganic antimony content of the control waste residue was $626.17 \mathrm{mg} \cdot \mathrm{kg}^{-1}$, and the inorganic antimony content of the rhizosphere and nonrhizosphere waste residue was $345.95-738.78 \mathrm{mg} \cdot \mathrm{kg}^{-1}$. The content of antimony(III) in the control residues and rhizosphere residues was significantly higher than that of antimony $(\mathrm{V})$. The contents of antimony $(\mathrm{III})$ and antimony $(\mathrm{V})$ in the rhizosphere waste residues of the 6 plants were significantly lower than those of the control waste residue and nonrhizosphere waste residue $(P<0.05)$. The ratios of arsenic(III) and antimony(III) to arsenic $(\mathrm{V})$ and antimony $(\mathrm{V})$, respectively, were higher than those of the control residues and nonrhizosphere residues.

\section{Effects of phytoremediation on the occurrence of arsenic and antimony in waste residue}

According to the morphology of arsenic and antimony in the waste residue (Figure 4), the morphology of arsenic and antimony in the waste residue after phytoremediation changed significantly compared with that in the control waste residue. The proportions of the occurrence forms of arsenic in the control slag were as follows, from high to low: residual state, exchangeable state, calcium-bound state, aluminum-bound state, and iron-bound state; the proportions of the occurrence forms of antimony were as follows, from high to low: calcium-bound state, exchangeable state, residual state, aluminum-bound state, and iron-bound state. The proportions of arsenic forms in the rhizosphere waste residues of plants were as follows, from high to low: residual state, exchangeable state, and calcium-bound state; the proportions of antimony were as follows, from high to low: residual state, calcium-bound state, exchangeable state, aluminum-bound state, and iron-bound state. The proportions of residual arsenic and antimony in the rhizosphere waste residue of plants were the highest and were significantly increased compared with those of the control waste residue; the proportions of exchangeable, aluminum-bound and calcium-bound arsenic and antimony were mostly lower than those of the control waste residue; the proportions of iron-bound arsenic and antimony were not significantly changed compared with those of the control waste residue. The proportions of residual arsenic and antimony in the rhizosphere waste residue were lower than that in nonrhizosphere waste residue, the proportion of exchangeable arsenic and antimony in the rhizosphere waste residues of Broussonetia papyrifera and Arundo donax was higher than that in nonrhizosphere waste residue, and the proportion of exchangeable arsenic and antimony in the rhizosphere waste residues of Cryptomeria fortunei and Robinia pseudoacacia was lower than that in nonrhizosphere waste residue.

\section{Distribution characteristics of arsenic and antimony in plant tissues}

As seen from Figure 5, the trends of arsenic and antimony in different plant tissues are obviously different. The arsenic content varied from 0.076 to $1.564 \mathrm{mg} \cdot \mathrm{kg}^{-1}$ in the tissues of the six plants. The order of arsenic content in the tissues of Broussonetia papyrifera, Cryptomeria fortunei and Arundo donax was root $>$ leaf $>$ stem, while the order of arsenic content in the tissues of Photinia serrulata was stem $>$ root $>$ leaf. The arsenic content in Lolium perenne roots was significantly higher than that in leaves $(P<0.05)$. The arsenic content in roots and leaves of Lolium perenne was significantly higher than that of other plants $(P<0.05)$, and the total arsenic content in the roots, stems and leaves of the six plants followed the order Lolium perenne > Photinia serrulata > Robinia pseudoacacia > Arundo donax > Broussonetia papyrifera > Cryptomeria fortunei. 
The antimony content in the tissues of the six plants varied from 0.022 to $0.488 \mathrm{mg} \cdot \mathrm{kg}^{-1}$. The antimony content in the tissues of Cryptomeria fortunei and Robinia pseudoacacia was in the order of root > leaf > stem; the antimony content in the tissues of Broussonetia papyrifera, Arundo donax and Photinia serrulata was in the order of root > stem > leaf; and the antimony content in the roots of Lolium perenne was significantly higher than that in the leaves $(P<0.05)$. The content of antimony in the roots and leaves of Lolium perennewas significantly higher than that of other plants $(P<0.05)$, and the total content of antimony in the roots, stems and leaves of the 6 plants followed the order Lolium perenne > Cryptomeria fortunei > Robinia pseudoacacia > Photinia serrulata $>$ Arundo donax $>$ Broussonetia papyrifera, from high to low.

The enrichment coefficients of arsenic and antimony in the waste residues of the 6 plants are shown in Table 2. The variation ranges of the enrichment coefficients of arsenic and antimony in the 6 plants are as follows: 0.00012-0.00064 and 0.00004-0.00021, respectively. The enrichment coefficients of arsenic and antimony in Lolium perenne were significantly higher than those in other plants.

Table 2. Enrichment coefficients of arsenic and antimony in plants

\begin{tabular}{|lll|}
\hline Plant species & \multicolumn{2}{l|}{ Enrichment coefficient } \\
\cline { 2 - 3 } & As & Sb \\
\hline Broussonetia papyrifera & 0.00014 & 0.00004 \\
\hline Cryptomeria fortunei & 0.00012 & 0.00013 \\
\hline Arundo donax & 0.00016 & 0.00007 \\
\hline Robinia pseudoacacia & 0.00018 & 0.00013 \\
\hline Photinia serrulata & 0.00016 & 0.00006 \\
\hline Lolium perenne & 0.00064 & 0.00021 \\
\hline
\end{tabular}

Enrichment coefficient = arsenic and antimony content in plant/arsenic and antimony content in waste residue.

\section{Physical and chemical properties of waste residue and principal component analysis of arsenic and antimony}

Figure 6 shows the physicochemical properties of the waste residues and the principal component analysis results of arsenic and antimony following phytoremediation. The first two principal components (PCA1 and PCA2) explained $72.35 \%$ of the total variation, and PCA1 and PCA2 explained $46.23 \%$ and $26.12 \%$ of the variation, respectively. In the waste residue, As, Sb, F2, F5, F2 and 44 had large positive loads on PCA1, while $\mathrm{Sb}(\mathrm{III}), \mathrm{Sb}(\mathrm{V}), \mathrm{F} 5$ and $\mathrm{pH}$ had negative loads on PCA1. As(III), As(V), Fed, Ald, F1, F3, F4, F1, F3, and Eh had positive loads on PCA2, and DOC had a negative load on PCA2. In general, $\mathrm{pH}$, Eh, free ferric oxide and aluminum showed a strong positive correlation with arsenic and antimony and a negative correlation with DOC.

The two-dimensional sequence diagram showed that the control waste residue samples were distributed on the positive axis of PCA2, which was positively correlated with arsenic, antimony, Eh and free iron and aluminum oxides in the waste residue and negatively correlated with DOC, indicating that the control waste residue 
contained higher contents of arsenic and antimony in various forms but very low contents of DOC. Plant root waste residue samples were mainly distributed along the negative axis of PCA2, which was positively correlated with DOC in waste residue, indicating that plant root waste residue had a lower arsenic and antimony content and higher DOC content.

\section{Discussion}

\section{Influence of phytoremediation on the physicochemical properties of waste residue}

Studies have shown that a decrease in $\mathrm{pH}$ value in the root environment is mainly attributed to the unbalanced absorption of positive and negative ions by plant roots, which results in the release of $\mathrm{H}^{+}$to neutralize the unbalanced charge of the plant roots $[29,30]$. Studies have also shown that the acidification of root exudates, litter and their degradation products and the release of $\mathrm{CO}_{2}$ by root respiration during plant responses to environmental stress may also cause a decrease in $\mathrm{pH}$ value [31, 32]. The acidification of the plant rhizosphere will accelerate the weathering of waste residue and affect the migration and transformation of arsenic and antimony in the waste residue, as well as the biological availability of these elements. The PCA analysis also showed that $\mathrm{pH}$ is positively correlated with arsenic and antimony.

Under the action of phytoremediation, the respiration of plant roots and microorganisms increased the partial pressure of $\mathrm{CO}_{2}$ in the waste residue and resulted in a decrease in the Eh value of the rhizosphere waste residue. For terrestrial plants, rhizosphere respiration makes antimony(III) in slag and thus improves the activity and toxicity of arsenic and antimony in soils [33]. The PCA analysis indicated that Eh was significantly positively related to arsenic and antimony.

DOC is strongly influenced by plants and microorganisms and plays an important role in soil nutrient supply. Active functional groups, including carboxyl, hydroxyl, carbonyl and methoxyl groups, can complex with arsenic and antimony to form inorganic complexes, affecting the morphology, migration, bioavailability and toxicity of arsenic and antimony. The PCA analysis showed that DOC is negatively correlated with arsenic and antimony, so it can be seen that an increase in DOC content in waste residue may reduce the content of arsenic and antimony. The amount of litter, the number of microorganisms, the content of metal ions in the soil and the $\mathrm{pH}$ value affect the DOC content.

Iron and aluminum oxides in soil are formed by the complete weathering of silicate minerals under specific hydrothermal conditions on the surface and have a significant impact on the physical and chemical properties of the soil [34]. Arsenic and antimony usually exist in soil in the form of neutral molecules or oxygen-containing anions [7]. Iron and aluminum oxides have a high point of zero charge (PZC) and are often positively charged on the surface of environmental media $[35,36]$. Therefore, the surface adsorption of iron and aluminum oxides an important mechanism for the fixation of arsenic and antimony in waste residues. The PZC of iron oxide is approximately 7; when the $\mathrm{pH}$ of the adsorption system is close to or more than the iron oxide PZC, the electronegativity of iron oxide will increase; the same charges of arsenic, antimony, and oxygen anion are mutually exclusive, leading to a decrease in the adsorption rate [37]. As a result, a lower $\mathrm{pH}$ of waste residue will increase the iron oxide adsorption of arsenic and antimony. The PZCs of various oxides of aluminum are 
approximately $\mathrm{pH}=6$, and these compounds present a net negative charge in neutral and alkaline environments. Therefore, the adsorption capacity of aluminum oxides for arsenic and antimony in waste residues is relatively weak. Arai et al. [38] also found the following in their study on the adsorption behavior of arsenic at the aluminum oxide-water interface: at $\mathrm{pH}=4.5$, the adsorption of aluminum oxide for arsenic in three days was almost $100 \%$, while at $\mathrm{pH}=7.8$, only $46 \%$ of the arsenic was absorbed in approximately one year. The PCA analysis also showed that free iron and aluminum oxide were positively correlated with arsenic and antimony, indicating that free iron and aluminum oxide might be related to the fixation of arsenic and antimony in waste residue.

\section{Influence of phytoremediation on the chemical structure of waste residue}

There are abundant active groups in waste residue, such as hydroxyl, carboxyl, phenolic hydroxyl, alcohol hydroxyl and other functional groups with acidic and substitution capacity, which can promote the adsorption of heavy metals by waste residue through ion exchange and complexation and play an important role in regulating the effectiveness of certain nutrients or heavy metals in the medium [39]. Wen et al. [40] also showed that two functional groups, hydroxyl and carboxyl groups, have a high affinity for heavy metals. Plant litter can increase the content of organic matter in soil; organic matter is mainly composed of polysaccharides, proteins, cellulose and lignin [41]. These substances are the main sources of carbohydrates, aliphatic groups and aromatic groups [42]. Furthermore, peptidoglycan, lipoprotein, cell proteins and other substances in soil microbial residues also increase the corresponding characteristic peak strength [43]. However, in this study, the peak strength of aliphatic and aromatic groups in rhizosphere waste residue was decreased, which may be related to the weathering and degradation of unburned coal remaining in the waste residue under the action of plants and microorganisms [44]. The characteristic functional groups in coal mainly include hydroxyl, phenolic hydroxyl, alcohol hydroxyl, carbonyl, amino, methoxy, aliphatic, aromatic and other groups [45]. The weathering degradation of coal in waste residue under phytoremediation may account for the lower absorption peak intensities at 3411, 2922, 2852 and $1624 \mathrm{~cm}^{-1}$ than those of the control waste residue. Polyphenol oxidase is mainly derived from soil microorganisms, rhizosphere secretions of plants and the decomposition of animal and plant residues [46] and is mainly involved in the transformation of aromatic organic compounds in humus components. The reduction in the characteristic peak strength of aromatic compounds may also be caused by the enhancement of polyphenol oxidase activity in the waste residue after phytoremediation. The dual peaks at

797 and $778 \mathrm{~cm}^{-1}$ are characteristic peaks of weathered quartz crystallization, representing amorphous silica and crystalline silica, respectively [47]. The exudates produced by plants and microorganisms play a pioneering role in the soil formation process of waste residue, which can corrode rocks and accelerate rock weathering. Laboratory simulations and field studies by Glowa et al. [48] and Kolo et al. [49] also demonstrated that arbuscular mycorrhizal fungi can dissolve silicate and carbonate minerals. Acid hydrolysis, extracellular polymerization and redox reactions of plants and microorganisms promote the weathering of minerals in waste residue, which may be the reason for the reduction of the characteristic peak strength of calcite and quartz.

\section{Influence of phytoremediation on the arsenic and antimony contents in waste residue}


The establishment of plants will change the waste residue microenvironment and promote the redistribution of arsenic and antimony forms in the waste residue. The arsenic and antimony contents are affected by a number of factors, including $\mathrm{pH}$, Eh, organic matter, iron and aluminum minerals, clay minerals, and plant root exudates. Slight changes in the external environmental conditions may cause immediate changes in the adsorption and desorption behavior of arsenic and antimony by waste residue, thus resulting in changes in their existing forms and contents. In this study, the contents of arsenic and antimony in the rhizosphere waste residues of the six plants were mostly lower than those of the control waste residue, which may be because phytoremediation became more effective and promoted plant absorption or because arsenic and antimony migrated beyond the root layer and percolated.

\section{Effects of phytoremediation on the valence characteristics of arsenic and antimony in waste residue}

The oxidation rate of arsenic sulfide decreases significantly with decreasing $\mathrm{pH}$ value in the plant rhizosphere [50], and the oxidation rate of antimony (III) to antimony $(\mathrm{V})$ decreases with increasing $\mathrm{pH}$ value [51].

Furthermore, the respiration of the plant rhizosphere and microorganisms causes the reduction of arsenic(V) and antimony $(\mathrm{V})$. These factors may have contributed to the increased proportion of arsenic(III) and antimony(III) in the rhizosphere waste residues. The adsorption of arsenic(III) and antimony(III) on the surface of iron and aluminum oxides is weaker than that of arsenic $(\mathrm{V})$ and antimony $(\mathrm{V})$, so the former compounds are easier to release. Moreover, a reduction in redox potential causes the reduction and dissolution of iron and aluminum oxides in waste residue, resulting in the release of arsenic and antimony adsorbed on the surface [52]. The competitive adsorption of organic matter with arsenic and antimony will affect the availability of arsenic and antimony in soil solution, and the microbial degradation of organic matter coupled with the reduction of ferro-aluminum minerals can inhibit the oxidation of arsenic and antimony, thus further promoting the dissolution of iron ore and the release of arsenic and antimony [53]. Dissolved carbonate can replace arsenic adsorbed on amorphous iron oxides, resulting in a decrease in arsenic adsorption and a greater effect on arsenic(III) than on arsenic(V) [54]. The leaching of carbonate minerals from waste residues due to weathering may also increase the availability of arsenic. The biological absorption and adsorption processes of arsenic and antimony depend on their morphology and microenvironment. Dissolved arsenic(III) and antimony(III) are easily absorbed by the rhizosphere of plants. Therefore, the reduction and release of arsenic and antimony in rhizosphere waste residue may increase absorption or leaching by plants and reduce the content of inorganic arsenic and antimony in rhizosphere waste residue.

\section{Effects of phytoremediation on the occurrence of arsenic and antimony in waste residue}

Research has shown that the total amount of a certain heavy metal in the soil cannot be used to truly evaluate its environmental behavior and ecological effect and that the morphological content and proportion of heavy metal in the soil are the key factors that determine its impact on the environment and the surrounding ecosystem [55]. Exchangeable heavy metals are the most active in the environment and are easily absorbed, leached or transformed by organisms, with high bioavailability. The ratio of exchangeable arsenic and antimony in the rhizosphere residues was lower than that of the control residues, which may be because the 
rhizosphere secretions and microbial activities of plants increased the availability of arsenic and antimony, promoted the absorption of arsenic and antimony, or activated arsenic and antimony that had migrated due to rainfall leaching. Research has shown $[56,57]$ that microbial degradation can significantly increase the humic acid content in lignite. Saada et al. [58] showed that the adsorption of humic acid on kaolinite in advance could provide new adsorption sites for arsenic, promote the adsorption of arsenic by kaolinite and reduce the activity of arsenic. A study by Guo et al. [59] showed that coal-based humic acid could significantly reduce the exchangeable arsenic content in soil, thus significantly reducing the available arsenic content in soil and promoting the growth of Chinese cabbage to some extent. Sun et al. [60] also showed that activation of weathered coal can reduce the mobility of arsenic in soil, increase the residual arsenic in soil, and reduce the toxic effect of arsenic on plants. After phytoremediation, the habitat of the waste residue was improved, and the microbial degradation of coal was enhanced, which may also be the reason for the decrease in the proportion of exchangeable arsenic and the increase in the proportion of residual arsenic. The decrease in free alumina content (Table 1) resulted in a decrease in the amount of arsenic and antimony adsorbed on alumina, which resulted in a decrease in the proportion of aluminum-bound arsenic and antimony in the plant rhizosphere waste residue. In neutral and alkaline soils, the precipitation of arsenic, antimony and $\mathrm{Ca}^{2+}$ is an important process controlling the availability of arsenic and antimony in soil [36]. After phytoremediation, precipitates of arsenic, antimony and $\mathrm{Ca}^{2+}$ may dissolve due to the decrease in $\mathrm{pH}$ value, leading to a decrease in the proportion of calcium-bound arsenic and antimony. Residual-state heavy metals generally exist in crystal lattices such as silicate, primary and secondary minerals, which are not easy to release under normal natural conditions, can exhibit long-term stability, and are not easily absorbed by plants. Their contents are mainly affected by mineral composition, rock weathering and soil erosion [61]. Exchangeable, calcium-bound, ironbound and aluminum-bound arsenic and antimony in waste residue are activated and absorbed by plants or are affected by weathering and leaching, and their contents gradually decrease, which may be the reason for the increase in the proportion of arsenic and antimony in the residual state.

\section{Distribution characteristics of arsenic and antimony in plants}

The normal contents of arsenic and antimony in plants are $<1 \mathrm{mg} \cdot \mathrm{kg}^{-1}$ and $<2.2 \mathrm{mg} \cdot \mathrm{kg}^{-1}$, respectively [62]. The contents of arsenic and antimony in the 6 plants grown on the waste residue mostly did not exceed these standards, and the enrichment coefficients of arsenic and antimony in the 6 plants were small, indicating that the enrichment capacity of arsenic and antimony was low. Arsenic and phosphorus are homologous elements, and the chemical properties of phosphate and pentavalent arsenates are similar. Thus, in higher plants, arsenates and phosphates share the same absorption transporter [63]. The reason why some plants can adapt to soil with high arsenic contamination is often because the absorption of arsenates is reduced by regulating the expression of phosphate transporters [64]. The six plants grown on waste residues in this study may inhibit the absorption of arsenic through this mechanism, thus avoiding physiological toxicity. When Pratas et al. [65] investigated trees and herbs growing on soil contaminated with antimony (the average concentration of antimony was $663 \mathrm{mg} \cdot \mathrm{kg}^{-1}$ ), they found that the content of antimony in the stems was less than $5 \mathrm{mg} \cdot \mathrm{kg}^{-1}$. Hammel et al. [66] studied 19 crops planted in the soil of the abandoned mining area and found that although the background value of antimony in the local soil was very high (up to $500 \mathrm{mg}^{\cdot \mathrm{kg}^{-1}}$ ), the content of antimony in the locally produced rice storage tissue was only $0.09 \mathrm{mg} \cdot \mathrm{kg}^{-1}$, and the maximum content of antimony in the 
stems and leaves was 0.34 and $2.2 \mathrm{mg} \cdot \mathrm{kg}^{-1}$, respectively. These studies show that plants have a strong ability to reject antimony, thus increasing their tolerance to antimony, and this study has similar results.

Plants growing on waste residue containing heavy metal elements will absorb the heavy metals by store heavy metals in their roots or will collect the heavy metals in the rhizosphere, reducing the flow via transfer and diffusion to the ground, thereby reducing harm to photosynthesis, respiration, and the reproductive system to maintain normal plant growth [67]. The highest arsenic and antimony content in the roots of the six plants growing on the waste residue may be related to this.

Although the enrichment capacity of arsenic and antimony is much weaker than that of hyperaccumulator, the response of these 6 kinds of plants to the higher levels of arsenic and antimony in the waste residue with respect to natural growth suggests that plants grown in the extreme habitat of waste residue have strong ecological adaptability; this adaptability is manifested in plants via mechanisms that block or reduce the absorption of high contents of arsenic and antimony from the growth environment to protect themselves from biological poisoning.

\section{Conclusions}

In this study, we found that after 7 years of phytoremediation, the $\mathrm{pH}$ and Eh of the rhizosphere waste residue of the six plants were significantly lower than those of waste residue $(P<0.05)$. The DOC content was significantly higher than that of the control waste residue $(P<0.05)$. The contents of arsenic, antimony and inorganic arsenic and antimony in the rhizosphere waste residue of the six plants were generally lower than those of the control waste residue. The proportions of arsenic and antimony in the rhizosphere waste residue increased compared with those of the control waste residue. The proportions of residual arsenic and antimony in the rhizosphere waste residue of the plants was the highest, and the proportions of exchangeable arsenic, the aluminum-bound state and the calcium-bound state were lower than that of the control waste residue. The arsenic and antimony contents in each tissue of the six plants varied from 0.076 to $1.564 \mathrm{mg} \cdot \mathrm{kg}^{-1}$ and 0.022 to $0.488 \mathrm{mg} \cdot \mathrm{kg}^{-1}$, respectively. The contents of arsenic and antimony in each plant followed the order roots > leaves > stems, and the enrichment coefficients of arsenic and antimony in different plants were small. In summary, after 7 years of phytoremediation, the content and bioavailability of arsenic and antimony in the waste residue decreased significantly, and the enrichment of arsenic and antimony in plant tissues was also low. It is speculated that the migration of arsenic and antimony in waste residue may be increased in the early stage of phytoremediation and the bioavailability of arsenic and antimony gradually decreases in the later stage.

\section{Abbreviations}

DOC: the dissolved organic carbon; FTIR: Fourier-transform infrared spectroscopy; PCA: principal component analysis; PZC: point of zero charge.

\section{Declarations}

\section{Acknowledgements}




\section{Authors' contribution}

Hang Sun: Designed the study, performed the experiments, Analysed the data, writing-Original draft preparation. Xinlong Li: Carried out a part of experiments. Yonggui Wu: contributed to the manuscript correction.

\section{Funding}

The study was funded by a grant from the United Fund of Guizhou Province Government and National Natural Science Foundation of China (No. U1612442), the National Natural Science Foundation of China (No. 41663009), and the Natural and Science Project of theEducation Department of Guizhou Province (No. KY2016011).

\section{Availability of data and materials}

The datasets used and/or analyzed during the current study are available from

the corresponding author on reasonable request.

\section{Ethics approval and consent to participate}

Not applicable.

\section{Consent for publication}

Not applicable.

\section{Competing interests}

The authors declare that they have no competing interests.

\section{Author details}

${ }^{1}$ College of Resource and Environmental Engineering, Guizhou University, Guiyang 550025, China. ${ }^{2}$ Institute of Applied Ecology, Guizhou University,Guiyang 550025, China. ${ }^{3}$ Guizhou Kast Environmental Ecosystem Observation and Research Station, Ministry of Education, Guiyang, 550025, China.

\section{References}

1. Nies, D. H (1999) Microbial heavy-metal resistance. Appl Microbiol Biot 51(6):730-750 
2. Gebel, T., Christensen, S., Dunkelberg, H (1997) Comparative and environmental genotoxicity of antimony and arsenic. Anticancer Res 17(4A):2603-2607

3. Mandal, B. K., Suzuki, K. T (2002) Arsenic round the world: a review. Talanta 58(1):201-235

4. Willis, S. S., Haque, S. E., Johannesson, K. H (2011) Arsenic and antimony in groundwater flow systems: a comparative study. Aquat Geochem, 17(6):775-807

5. Cullen, W. R., Reimer, K. J (1989) Arsenic speciation in the environment. Chem Rev 89(4):713-764

6. Filella, M., Belzile, N., Chen, Y. W (2002) Antimony in the environment: a review focused on natural waters: I. Occurrence. Earth Sci Rev, 57(1-2):125-176

7. Mitsunobu, S., Harada, T., Takahashi, Y (2006) Comparison of antimony behavior with that of arsenic under various soil redox conditions. Environ Sci Technol, 40(23):7270-7276

8. Majzlan, J., Lalinská, B., Chovan, M., Bläß, U., Brecht, B., Göttlicher, J., Gescher, J (2011) A mineralogical, geochemical, and microbiogical assessment of the antimony-and arsenic-rich neutral mine drainage tailings near Pezinok, Slovakia. Am Mineral, 96(1):1-13

9. Shumilin, E., Federico Páez-osuna, Green-Ruiz, C., Sapozhnikov, D., L Godínez-Orta (2001) Arsenic, antimony, selenium and other trace elements in sediments of the la paz lagoon, peninsula of baja california, mexico. Mar Pollut Bull, 42(3):174-178

10. Kelepertsis, A., Alexakis, D., Skordas, K (2006) Arsenic, antimony and other toxic elements in the drinking water of Eastern Thessaly in Greece and its possible effects on human health. Environ Geol, 50(1):76-84

11. Pérez-Sirvent, C., Martínez-Sánchez, M. J., Martínez-López, S., Bech, J., Bolan, N (2012) Distribution and bioaccumulation of arsenic and antimony in Dittrichia viscosa growing in mining-affected semiarid soils in southeast Spain. J Geochem Explor, 123: 128-135

12. Luo, Y., Wu, Y., Xing, R., Wang, H., Shu, J., Wu, Z., Wan, Z (2018) Assessment of chemical, biochemical, and microbiological properties in an artisanal Zn-smelting waste slag site revegetated with four native woody plant species. Appl Soil Ecol: 124, 17-26

13. Pilon-Smits, E (2005) Phytoremediation. Annu Rev Plant Biol., 56:15-39

14. Watt, M., Silk, W. K., Passioura, J. B (2006) Rates of root and organism growth, soil conditions, and temporal and spatial development of the rhizosphere. Ann Botan, 97(5):839-855

15. Kidd, P., Barceló, J., Bernal, M. P., Navari-Izzo, F., Poschenrieder, C., Shilev, S., Monterroso, C (2009) Trace element behaviour at the root-soil interface: implications in phytoremediation. Environ Exp Bot, 67(1):243-259

16. Tao, S., Liu, W. X., Chen, Y. J., Xu, F. L., Dawson, R. W., Li, B. G., Fang, J. Y (2004) Evaluation of factors influencing root-induced changes of copper fractionation in rhizosphere of a calcareous soil. Environ Pollut, 129(1):5-12

17. Riley, D., Barber, S. A (1969) Bicarbonate accumulation and pH changes at the soybean (Glycine max (L.) Merr.) root-soil interface. Soil Sci Soc Am J, 33(6):905-908

18. Riley, D., Barber, S. A (1970) Salt Accumulation at the Soybean (Glycine Max.(L.) Merr.) Root-Soil Interface 1. Soil Sci Soc Am J, 34(1):154-155

19. Bolan, N. S., Baskaran, S., Thiagarajan, S (1996) An evaluation of the methods of measurement of dissolved organic carbon in soils, manures, sludges, and stream water. Commun Soil Sci Plan, 27(13- 
14):2723-2737

20. Lu, R.K (2000) Analytical Methods of Soil and Agricultural Chemistry. China Agricultural Science and Technology Press, Beijing

21. Fuentes, E., Pinochet, H., De Gregori, I., Potin-Gautier, M (2003) Redox speciation analysis of antimony in soil extracts by hydride generation atomic fluorescence spectrometry. Spectrochimica Acta Part B: Atom Spectrosc, 58(7):1279-1289

22. Xiao, E., Krumins, V., Xiao, T., Dong, Y., Tang, S., Ning, Z., Sun, W (2017) Depth-resolved microbial community analyses in two contrasting soil cores contaminated by antimony and arsenic. Environ Pollut, 221:244-255

23. Sun, W., Xiao, E., Xiao, T., Krumins, V., Wang, Q., Häggblom, M., Xia, B (2017) Response of soil microbial communities to elevated antimony and arsenic contamination indicates the relationship between the innate microbiota and contaminant fractions. Environ Sci Tchnol, 51(16):9165-9175

24. Onken, B. M., Adriano, D. C (1997) Arsenic availability in soil with time under saturated and subsaturated conditions. Soil Sci Soc of Am J, 61(3):46-752

25. Gleyzes, C., Tellier, S., Astruc, M (2002) Fractionation studies of trace elements in contaminated soils and sediments: a review of sequential extraction procedures. TrAC Trend Anal Chem, 21(6-7):451-467

26. Madejová, J (2003) FTIR techniques in clay mineral studies. Vib spectrosc, 31(1):1-10

27. Celi, L., Schnitzer, M., Nègre, M (1997) Analysis of carboxyl groups in soil humic acids by a wet chemical method, Fourier-transform infrared spectrophotometry, and solution-state carbon-13 nuclear magnetic resonance. A comparative study. Soil Sci, 162(3):189-197

28. Mao, J., Olk, D.C., Fang, X., He, Z., Schmidt-Rohr, K (2008) Influence of animal manure application on the chemical structures of soil organic matter as investigated by advanced solid-state NMR and FT-IR spectroscopy. Geoderma, 146(1-2):353-362

29. Nye, P. H (1981) Changes of pH across the rhizosphere induced by roots. Plant Soil, 61(1-2):7-26

30. Hinsinger, P., Plassard, C., Tang, C., Jaillard, B (2003) Origins of root-mediated pH changes in the rhizosphere and their responses to environmental constraints: a review. Plant Soil, 248(1-2):43-59

31. Pennanen, T., Strömmer, R., Markkola, A., Fritze, H (2001) Microbial and plant community structure across a primary succession gradient. Scand J Forest Res, 16(1):37-43

32. Baldrian, P., Valášková, V (2008) Degradation of cellulose by basidiomycetous fungi. Fems Microbiol rev, 32(3):501-521

33. Yamaguchi, N., Ohkura, T., Takahashi, Y., Maejima, Y., Arao, T (2014) Arsenic distribution and speciation near rice roots influenced by iron plaques and redox conditions of the soil matrix. Environ Sci Technol, 48(3):1549-1556

34. Schwertmann, U., Kodama, H., Fischer, W.R (1986) Mutual Interactions between organics and iron oxides, In: Huang, P.M., Schnitzer, M. (ed) Interactions of Soil Minerals with Natural Ž. Organics and Microbes, Soil Sci. Soc. Am., Madison, WI, pp. 223-250

35. Mitsunobu, S., Takahashi, Y., Terada, Y., Sakata, M (2010) Antimony (V) incorporation into synthetic ferrihydrite, goethite, and natural iron oxyhydroxides. Environ Sci Technol, 44(10):3712-3718 
36. Wilson, S. C., Lockwood, P. V., Ashley, P.M., Tighe, M (2010) The chemistry and behaviour of antimony in the soil environment with comparisons to arsenic: a critical review. Environ pollut, 158(5):1169-1181

37. Bowell, R. J (1994) Sorption of arsenic by iron oxides and oxyhydroxides in soils. Appl geochem, 9(3):279286

38. Arai, Y., Sparks, D. L (2002) Residence time effects on arsenate surface speciation at the aluminum oxidewater interface. Soil Sci, 167(5):303-314

39. Huang, M., Zhu, Y., Li, Z., Huang, B., Luo, N., Liu, C., Zeng, G (2016) Compost as a soil amendment to remediate heavy metal-contaminated agricultural soil: mechanisms, efficacy, problems, and strategies. Water Air Soil Poll, 227(10):359

40. Wen, J., Li, Z., Huang, B., Luo, N., Huang, M., Yang, R., Zeng, G (2018) The complexation of rhizosphere and nonrhizosphere soil organic matter with chromium: Using elemental analysis combined with FTIR spectroscopy. Ecotox Environ Safe, 154:52-58

41. Lehmann, J., Solomon, D., Kinyangi, J., Dathe, L., Wirick, S., Jacobsen, C (2008) Spatial complexity of soil organic matter forms at nanometre scales. Nat Geosci, 1(4):238-242

42. Chen Q Y, Wu Y Q, Lei T Z, Si G C, Zhang G X (2018) Study on the fingerprints of soil organic components in alpine grassland based on Py \GC区MS / MS Technology. Acta Ecologica Sinica, 38(8):2864囚 2873.43

43. Kögel-Knabner, I (2002). The macromolecular organic composition of plant and microbial residues as inputs to soil organic matter. Soil Biol Biochem, 34(2):139-162

44. Gupta, R. K., Deobald, L. A., Crawford, D. L (1990) Depolymerization and chemical modification of lignite coal byPseudomonas cepacia strain DLC-07. Appl Biochem Biotech, 24(1):899-911

45. Butuzova, L., Krzton, A., Bazarova, O (1998) Structure and properties of humic acids obtained from thermooxidised brown coal. Fuel, 77(6):581-584

46. Duran, N., Esposito, E (2000) Potential applications of oxidative enzymes and phenoloxidase-like compounds in wastewater and soil treatment: a review. Appl Catal B- Environ, 28(2):83-99

47. Madejova, J., Komadel, P (2001) Baseline studies of the clay minerals society source clays: infrared methods. Clay Clay Miner, 49(5):410-432

48. Glowa, K. R., Arocena, J. M., Massicotte, H. B (2003) Extraction of potassium and/or magnesium from selected soil minerals by Piloderma. Geomicrobiol J, 20(2):99-111

49. Kolo, K., Claeys, P (2005) In vitro formation of Ca-oxalates and the mineral glushinskite by fungal interaction with carbonate substrates and seawater. Biogeosciences, 2:277-293

50. Lengke, M. F., Tempel, R. N (2005) Geochemical modeling of arsenic sulfide oxidation kinetics in a mining environment. Geochim Cosmochim Ac, 69(2):341-356

51. Belzile, N., Chen, Y. W., Wang, Z (2001) Oxidation of antimony (III) by amorphous iron and manganese oxyhydroxides. Chem Geol, 174(4):379-387

52. Sparks, D. L (2003) Environmental soil chemistry. Elsevier, Amsterdam

53. Sodano, M., Said-Pullicino, D., Fiori, A. F., Catoni, M., Martin, M., Celi, L (2016) Sorption of paddy soil-derived dissolved organic matter on hydrous iron oxide-vermiculite mineral phases. Geoderma, 261:169-177

54. Appelo, C. A. J., Van der Weiden, M. J. J., Tournassat, C., Charlet, L (2002) Surface complexation of ferrous iron and carbonate on ferrihydrite and the mobilization of arsenic. Environ Sci Technol, 36(14):3096-3103 
55. Allen, H. E., Hall, R. H., Brisbin, T. D (1980) Metal speciation. Effects on aquatic toxicity. Environ Sci Technol, 14(4):441-443

56. Yuan Hongli, Cai Yaqi, Zhou Xigui, Chen Wenxin (2000) Study on chemical properties of humic acid of microboal degraded lignite. Environmental Chemistry, 19(3):420-243

57. Yuan Hongli, Jiang Feng, Gao Tongguo (2009) Study on biotechnology application in producing fulvic acid by degraded lignite. Humic Acid, (5):1-5

58. Saada, A., Breeze, D., Crouzet, C., Cornu, S., Baranger, P (2003) Adsorption of arsenic (V) on kaolinite and on kaolinite-humic acid complexes: role of humic acid nitrogen groups. Chemosphere, 51(8):757-763

59. Guo, L., Yushan, B. U (2017) Effects of coal-based humic acid on soil arsenic occurrence form,the growth and arsenic absorption and distribution of pakchoi. Journal of Soil and Water Conservation, 31(4):332337

60. SUN Yan, XU Yuxin, LUO Hongyi (2015) Effects of weathered coal activated by ultrasonic on soil arsenic forms and soil enzyme activity, Journal of Soil and Water Conservation, 5:144-145

61. Presley, B. J., Trefry, J. H., Shokes, R. F (1980) Heavy metal inputs to Mississippi Delta sediments. Water Air Soil Poll, 13(4):481-494

62. Dudka, S., Adriano, D. C (1997) Environmental impacts of metal ore mining and processing: a review. J Environ Qual, 26(3):590-602

63. Asher, C. J., Reay, P. F (1979) Arsenic uptake by barley seedlings. Funct Plant Biol, 6(4):459-466

64. Meharg, A. A., Hartley-Whitaker, J (2002) Arsenic uptake and metabolism in arsenic resistant and nonresistant plant species. New Phytol, 154(1):29-43

65. Pratas, J., Prasad, M. N. V., Freitas, H., Conde, L (2005) Plants growing in abandoned mines of Portugal are useful for biogeochemical exploration of arsenic, antimony, tungsten and mine reclamation. J Geochem Explor, 85(3):99-107

66. Mendez, M. O., Maier, R. M (2008) Phytostabilization of mine tailings in arid and semiarid environmentsan emerging remediation technology. Environ Health Persp, 116(3):278-283

\section{Figures}



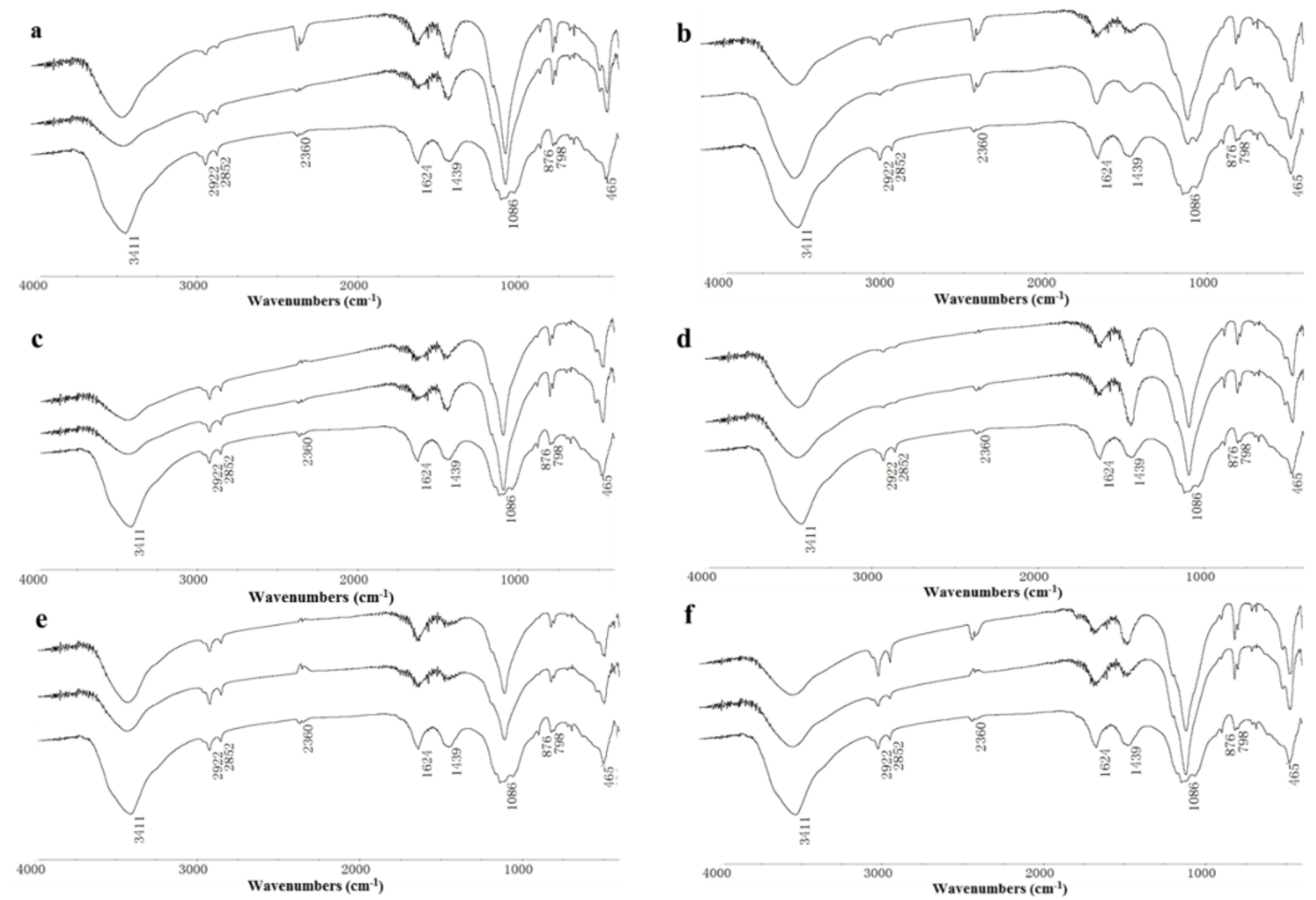

\section{Figure 1}

FTIR spectra of waste residues with respect to different plants. The three spectral lines from top to bottom of each figure correspond to rhizosphere waste residue, nonrhizosphere waste residue and control waste residue in turn. $a-f$ corresponds to waste residues under the influence of Broussonetia papyrifera, Cryptomeria fortunei, Arundo donax, Robinia pseudoacacia, Photinia serrulata and Lolium perenne. 

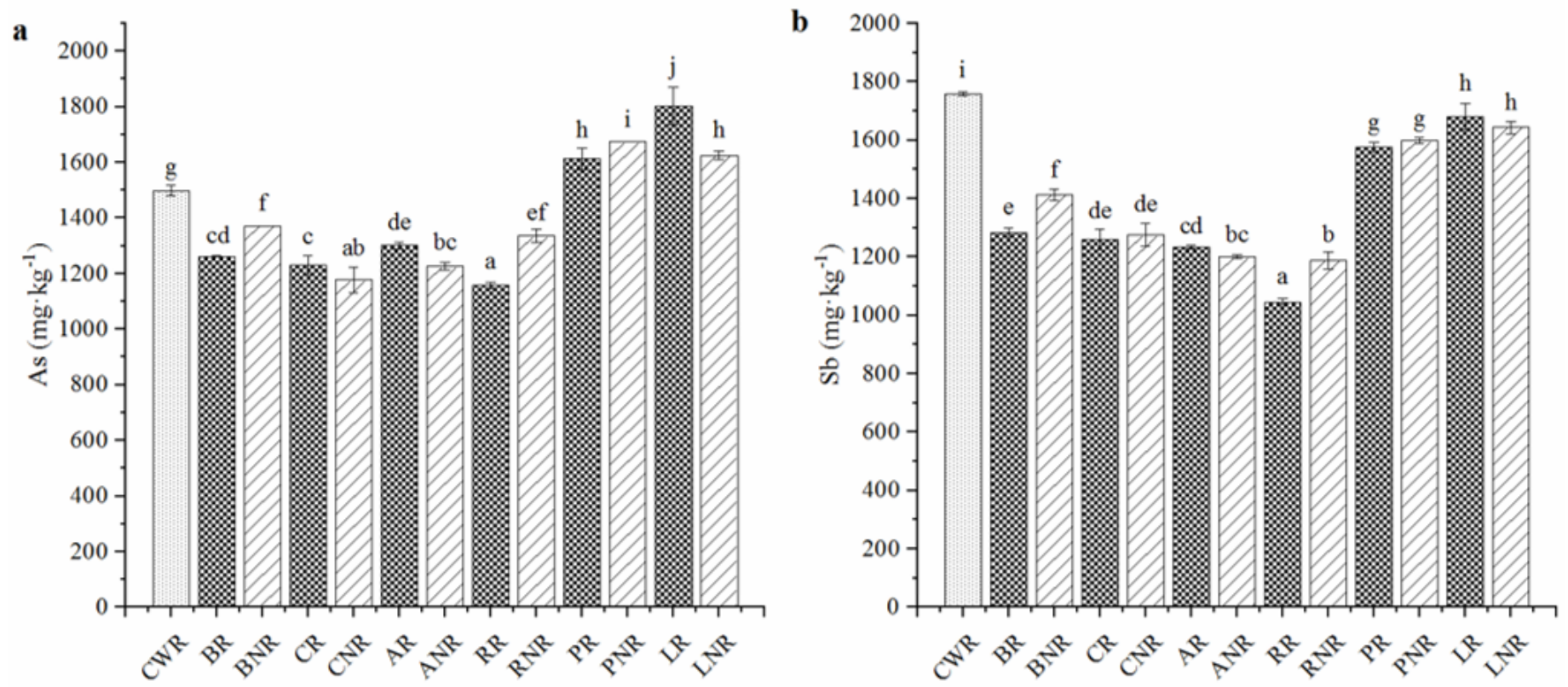

\section{Figure 2}

Influence of phytoremediation on the arsenic (a) and antimony (b) content in waste residue
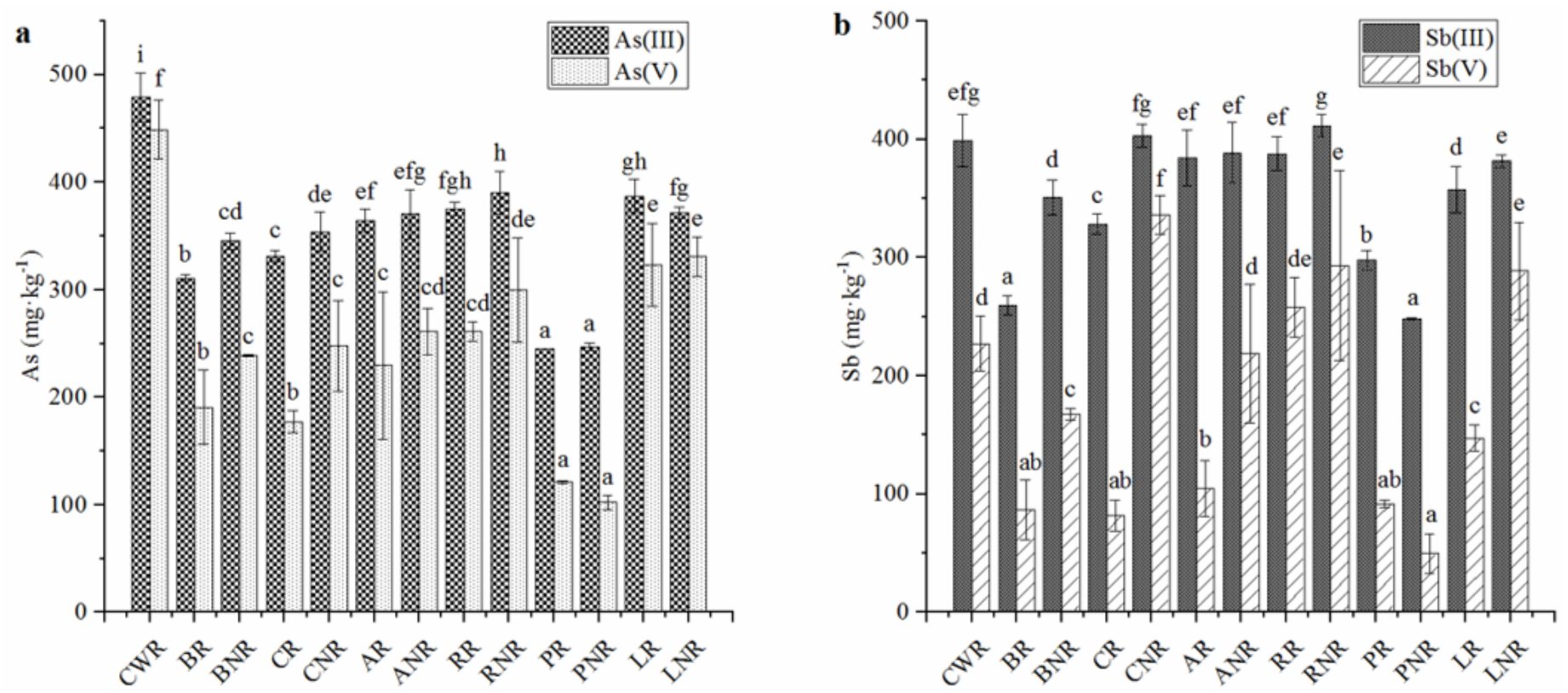

Figure 3

Influence of phytoremediation on the valence state of arsenic (a) and antimony (b) in waste residue 


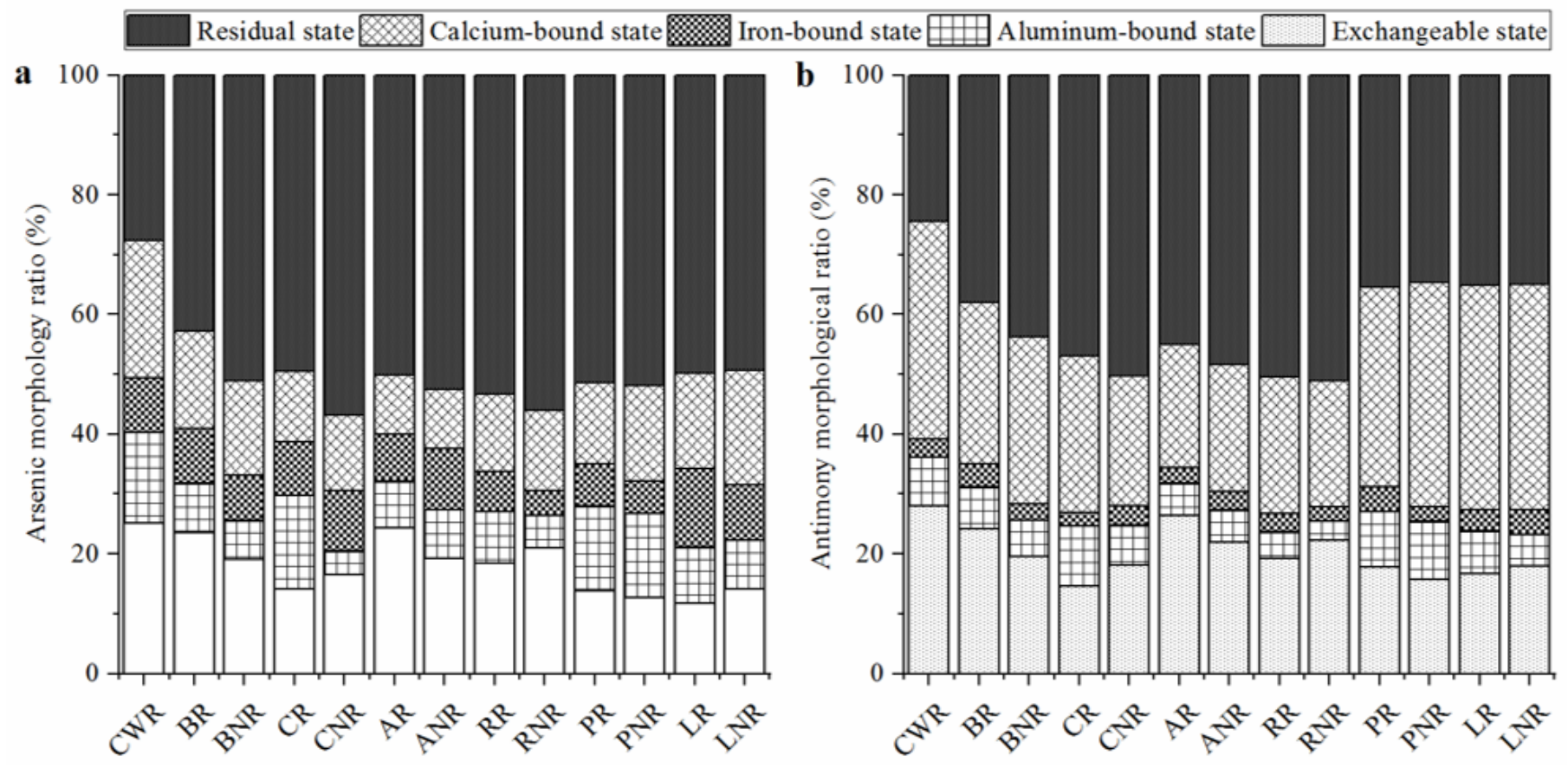

Figure 4

Influence of phytoremediation on the occurrence of arsenic (a) and antimony (b) in waste residue
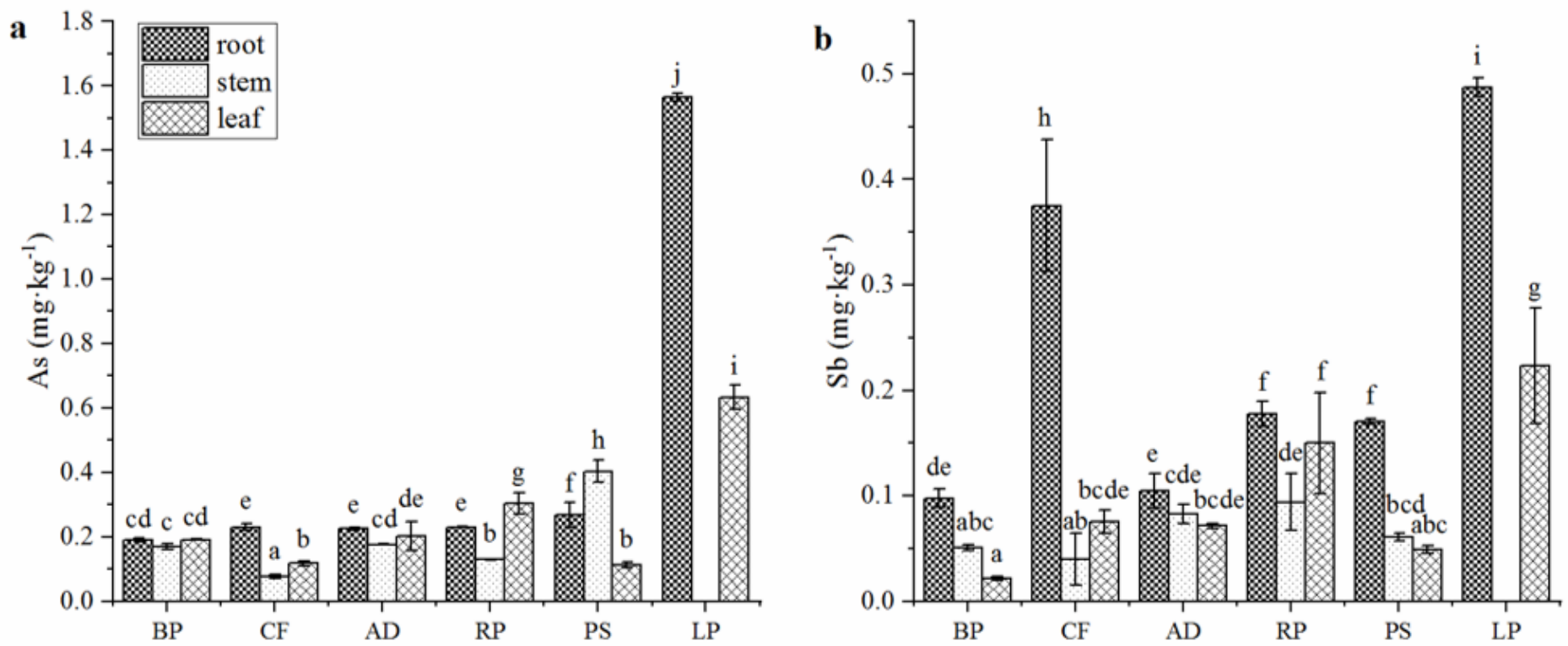

Figure 5

Distribution characteristics of arsenic (a) and antimony (b) in plant tissues. BP = Broussonetia papyrifera; $C F=$ Cryptomeria fortunei; $A D=$ Arundo donax; $R P=$ Robinia pseudoacacia; $P S=$ Photinia serrulata; $L P=L o l i u m$ perenne. 


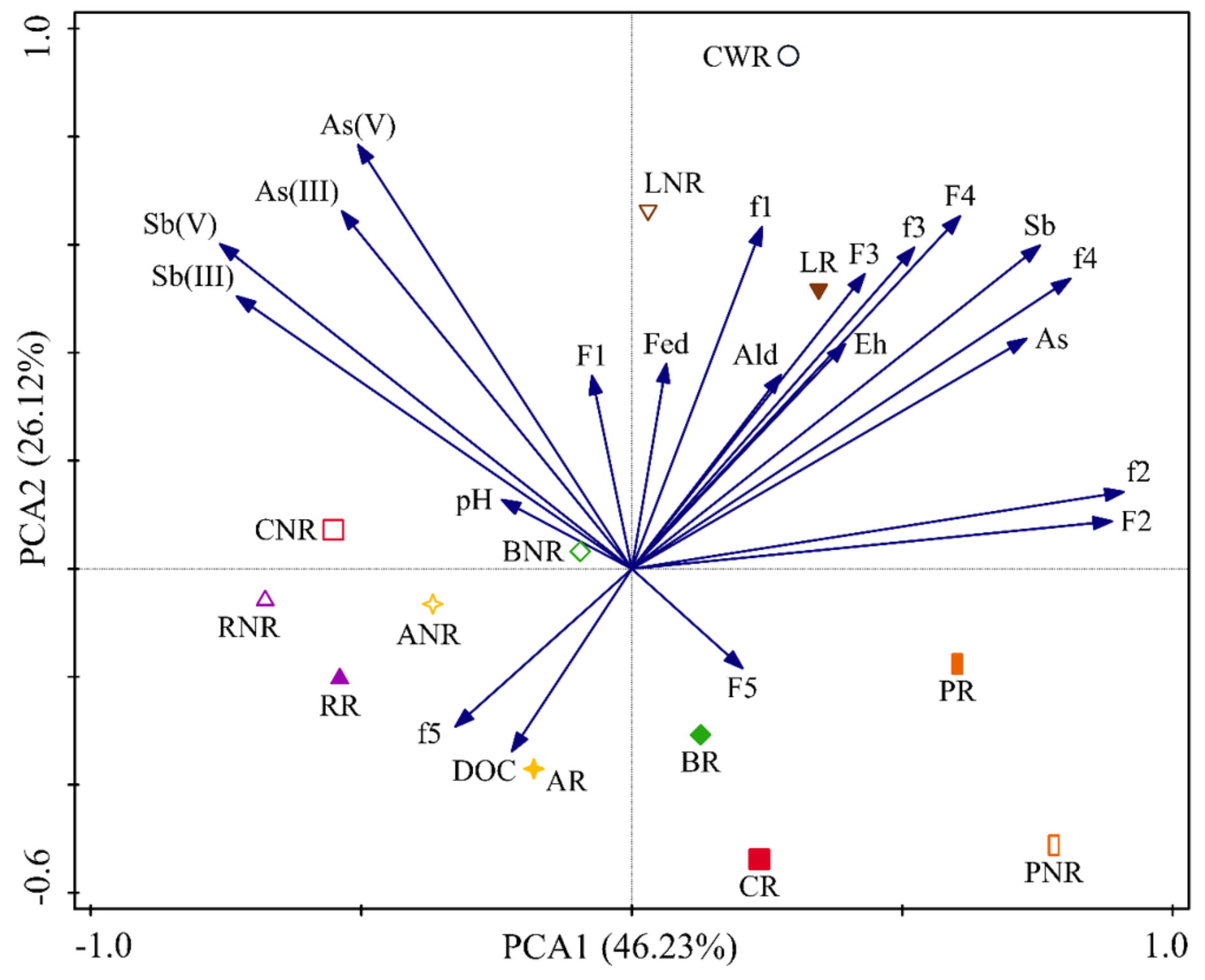

Figure 6

Physical and chemical properties of waste residue and principal component analysis of arsenic and antimony. F1-5 and f1-5 represent exchangeable state, aluminum-bound state, iron-bound state, calcium-bound state and residual state arsenic and antimony respectively. 